\title{
Effectiveness of Animation Media toward Teaching Deaf Students on Dental Hygiene
}

\author{
Sariyem*, Bedjo Santoso, Supriyana \\ Poltekkes Kemenkes Semarang, Indonesia \\ *Corresponding Author: Sariyem, Politeknik Kesehatan, Kemenkes Semarang, Jl. Tirto Agung \\ Pedalangan, Banyumanik, Indonesia.
}

\begin{abstract}
Background: Deaf is the disabled with hearing disorders. A prominent characteristic of deaf children is verbal communication disorders, lost all or part of the power of hearing and uses sign language to communicate. Limitations of deaf children causing bottlenecks in the health care of teeth and mouth. Deaf children with hearing resulted in more diverting obstacles to the functioning of the visual observations so much time spent deaf children to learn to understand other people's language and intent of what is seen from the people around.
\end{abstract}

The Objective: The study aims to determine the effectiveness of media animation for knowledge and plaque score deaf students.

Method: This type of research is a quasi-experiment with a pretest-posttest design with the control group. The sample represents a total population 30 people who consist of the intervention group and the control group, and each totaled 15 people.

Result: The results showed the increase in the value of knowledge and a decrease in plaque score was not significant in the control group. On the other hand, increase the knowledge and decrease plaque scores in the intervention group were significant.

Conclusion: Unique and special teaching media should be developed to teach the deaf students in order they are able to take care of their dental health.

Keywords: Animation, knowledge, plaque score, deaf

\section{INTRODUCTION}

The problem of oral health not only experienced by children of primary school age with an average body condition but also experienced by school children with disabilities. Disability is any person with a physical or mental defect that may interfere with or constitute obstacles and barriers for him to perform activities properly.

According to Norahmasari (2014), people with hearing loss will result in the disruption of behavior towards the maintenance of oral health, so that health and oral hygiene level is lower when compared with healthy people. Behavior in maintaining oral health is an essential component in the improvement of oral health status of children with hearing impairment.

The behavior of dental and oral health maintenance can be enhanced through dental health education with appropriate counseling appropriate method so that the message can be received by the target. The extension is an educational activity to disseminate information and to instill confidence, so that people are not only aware, know and understand, but also willing and able to make a suggestion that has to do with health.

Results of a preliminary study on a class of deaf is difficult to transfer the material, which can be conveyed and accepted for the type of deaf students to go through several stages: hard intonation, apparently accompanied by facial expression, verbal pronunciation clear lip and must be accompanied by repetition more than twice. These cannot be done customarily and must be accustomed to classroom teachers for teaching the deaf.

Media with a high visual power is required to support successful learning and understanding 
of deaf children. One form of media with high optical power is a video animation. According to Sumaryanti (2010), video media is one medium that has the advantage for appearance and explanations can be repeated to add clarity to counsel the children. Bektiningsih (2009) argues that the animation has a visual aspect and can give precise information than just words that are expected to enhance the knowledge of the deaf.

\section{METHODS}

The study was a quasi experiment with $a$ pretest-posttest design with the control group.

The research sample is total population some 30 deaf students comprising the control group and the intervention groups each consisting of 15 people. Differences in the two teams are the animation media applications in the intervention group. Before the intervention, respondents

Table1. Normality test of the data research performed math and Indonesian language tests. Deaf children with excellent math skills will have the ability to think abstractly and sound logic. In addition to mathematical knowledge, deaf students should have a remarkable understanding of Indonesian language understanding as the deaf students are difficult to understand abstract words. The adequacy of the use of Indonesian language is used to illustrate concrete examples to facilitate deaf students. The test of homogeneity of variances was conducted to identify if the characteristics of the two groups were homogeneous. Furthermore, the data are analyzed and presented in tabular form.

\section{RESULTS}

Normality test using Shapiro Wilk test indicates that the data are typically distributed as the pvalue is above 0.05 .

\begin{tabular}{|l|l|l|}
\hline group & Variable & p-value \\
\hline \multirow{4}{*}{ Counseling } & Knowledge before & 0,293 \\
\cline { 2 - 3 } & Knowledge after & 0.082 \\
\cline { 2 - 3 } & Plaque score before & 0.129 \\
\cline { 2 - 3 } & Plaque score after & 0.088 \\
\hline \multirow{4}{*}{ Animation } & Knowledge before & 0.262 \\
\cline { 2 - 3 } & Knowledge after & 0.097 \\
\cline { 2 - 3 } & Plaque score before & 0.568 \\
\cline { 2 - 3 } & Plaque score after & 0.334 \\
\hline
\end{tabular}

Statistical test with paired t-test showed an increase in knowledge in both groups that experienced a significant increase proved the value of $p=0.000(p<0.05)$. Results of the significance of the value of knowledge can be seen in Table 2.

Table2. The significance of knowledge value

\begin{tabular}{|l|l|l|l|c|}
\hline Group & Variable & Mean & Standard Deviation & p-value \\
\hline \multirow{2}{*}{ Counseling } & Knowledge before & 7,000 & 1.25357 & 0,000 \\
\cline { 2 - 4 } & After counseling & 12,400 & 0.98561 & \\
\hline \multirow{2}{*}{ Animation } & Knowledge before & 6.7333 & 1.16292 & 0.000 \\
\cline { 2 - 4 } & After intervention & 12.200 & 2.11119 & \\
\hline
\end{tabular}

Test statistics by paired t-test showed that the reduction in plaque scores in both groups that experienced a significant decline proved with the value of $p=0.000(p<0.05)$. Results significance of plaque score value can be seen in Table 3.

Table3. Significance values plaque score

\begin{tabular}{|l|l|l|l|c|}
\hline Group & Variable & Mean & Standard Deviation & p-value \\
\hline \multirow{2}{*}{ Extension } & Plaque score before & 3.960 & 0.64675 & \multirow{2}{*}{0.000} \\
\cline { 2 - 4 } & Plaque score after & 0.9200 & 0.73892 & \\
\hline \multirow{2}{*}{$\begin{array}{l}\text { Animated } \\
\text { Movies }\end{array}$} & Plaque score before & 3.2400 & 0.84160 & \multirow{2}{*}{0.000} \\
\cline { 2 - 4 } & Plaque score after & 0.8400 & 0.51934 & \\
\hline
\end{tabular}

Table 4 shows that increased knowledge and decrease plaque score in the counseling group did not experience significant improvement proved with the value of $p>0.05$. Dental health education through screenings of animated films showed increased knowledge, and impairment plaque score significantly proved with the value of $\mathrm{p}<0.05$. 
Table4. Effectiveness of dental health education between the extension methods animated film screenings

\begin{tabular}{|l|l|l|l|}
\hline Groups & Variable & p-value & Notes \\
\hline \multirow{2}{*}{ Extension } & Knowledge of & 0.899 & Not significant \\
\cline { 2 - 4 } & plaque score & 0.899 & No significant \\
\hline \multirow{2}{*}{ Animated Film } & Knowledge of & 0.048 & Significant \\
\cline { 2 - 4 } & Plaque score & 0.049 & Significant \\
\hline
\end{tabular}

The research was deaf students, one the considerations that form the basis for the homogeneity is the value of mathematics and Indonesian. Limitations of children with hearing impairment cause cognitive development becomes blocked so that deaf children should have an excellent logical ability. According to research Charles (2010), deaf children with excellent math skills will have the ability to think abstractly and sound logic.

In addition to mathematical ability, deaf students should have an excellent ability to the Indonesian language. This is due to deaf students is difficult to understand abstract and figurative words that the adequacy of the use of the language to illustrate concrete examples can facilitate deaf students (Hastuti \& Andriyani, 2010).

The increased value of knowledge and a decrease in plaque score but in the counseling group showed no significant change might be because the extension is not understood well by deaf students as the material presented is given conventionally. According to Kaur et al. (2013), simple extension / conventional is delivered content using only the board and sign language. Providing counseling on deaf not only lead students to be able to build their knowledge but also participated with students to form new knowledge in students, making meaning, looking for clarity, and identifying what was critical of the things that have been learned.

Submission of materials or counseling conventionally made deaf students do not fully understand the material being taught as children with hearing problems; they have a hearing obstacles and difficulties to communicate verbally with others (Salmiah, 2010).

Increased knowledge (0.048) and a decrease in plaque score (0.049) on dental health education through screenings of animated films show significant changes. This condition is caused by a deaf child is more dominant in the visual view. This is supported by Shukla, et al. (2014) states that a deaf child with hearing resulted in more diverting obstacles to the functioning of the visual observations so much time spent by deaf children to learn to understand other people's language and intent of what is seen from the people surrounding.

The animated movie is a multimedia that is packaged in a more vibrant and capable of simulating material being taught to be more attractive to make deaf students appreciate and understand the stuff being explained to them. Teaching methods using multimedia for teaching deaf students is advantageous to be applied in special education in Indonesia. According to Ajami, et al.(2007) animated film materials attract student interest and help students understand the material. Audio is used as a support and to explain the article according to the script material that has been made.

\section{CONClusion}

Dental health education with animation media is effective in improving knowledge and decrease plaque score of deaf students.

\section{REFERENCES}

[1] Ajami BA, Shabzendedar M, Rezay YA, Asgary M. Dental Treatment Needs of Children with Disabilities. JODDD.2007; 1; 2.

[2] Bektiningsih, K. 2009. Program Terapi Anak Autis Di SLB Negeri Semarang. Jurnal kependidikan, Volume 39, Nomor 2, November 2009.Jurusan Pendidikan Guru Sekolah Dasar (PGSD) - FIP UniversitasNegeri Semarang

[3] Charles JM. Dental Care in Children with Developmental Disabilities: Attention Deficit Disorder, Intellectual Disabilities, and Autism. J Dent Child (Chic).2010; 77; 84-91.

[4] Darby, Walsh. Dental Hygiene Theory and Practice $2^{\text {nd }}$ Edition. Saunders. USA. 2003.

[5] Erlina R, Larasati TA, Kurniawan, B. 2013. Faktor-Faktor Yang Mempengaruhi Ibu Hamil terhadap Kunjungan Pemeriksaan Kehamilan Di Puskesmas Rawat Inap Panjang Bandar Lampung. Medical Journal of Lampung University Volume 2 No 4 Februari 2013 ISSN 2337-3776 P. 29-34

[6] Gomes, Faustino Cardoso, 2000. Manajemen Sumber Daya Manusia, Edisi Pertama, Cetakan Kedua, PenerbitAndi Offset, Yogyakarta.

[7] Hastuti, S. Andriyani, A. 2010. Perbedaan Pengaruh Pedidikan Kesehatan Gigi Dalam Meningkatkan Pengetahuan Tentang Kesehatan 
Gigi Pada Anak Di Sd Negeri 2 Sambi Kecamatan Sambi Kabupaten Boyolali. Jurnal ilmu Kesehatan. GASTER, Vol. 7, No. 2 Agustus 2010 (624-632). Prodi S 1 Keperawatan Sekolah Tinggi Ilmu Kesehatan Aisyiyah Surakarta

[8] Jeng W, Wang T, Cher T, Lin C, Jeng J. Strategies for Oral Health Care for People with Disabilities in Taiwan.J Dent Sci. 2009; 4(4); 165-172.

[9] Kaur S, Malhotra R, Kaur H, Battu VS, Kaur A. Oral Hygiene Status of Mentally and Physically Challenged Individuals Living in a Specialized Institution in Mohali India. Indian Journal of Oral Sciences .2013; 4; 1.

[10] Mangkupawira, 2004. Manajemen Sumber Daya Manusia Strategik, Cetakan ketiga, Penerbit Ghalia Indonesia, Jakarta.

[11] Norahmasari, D. 2014. Dukungan Sosial Keluarga Dengan Tingkat Kepercayaan Diri Anak Yang Mengalami Tunarungu. Jurnal Online Psikologi Vol. 02 No. 02, Thn. 2014 http://ejournal.umm.ac.id. FakultasPsikologi, Universitas Muhammadiyah Malang

[12] Notoatmodjo, S. 2010. Pendidikan dan Perilaku Kesehatan. Jakarta. Rineka Cipta.

[13] Petersen, P. E., Kandelamn, D., Arpin, S., \& Ogawa, H. (2010). Global oral health of older people - Call for public health action. Community Dental Health, 27, 257-268.

[14] Putri, M. H., Herjulianti, E., Nurjannah, N., 2011, Ilmu Pencegahan Penyakit Jaringan Keras Dan Jaringan Pendukung Gigi, EGC, Jakarta.

[15] Rivai, Veithzal, 2006. Manajemen Sumber Daya Manusia Untuk Perusahaan, Dari Teori ke
Praktek, Edisi Pertama, Cetakan Ketiga, Penerbit PT. Raja GrafindoPersada, Jakarta.

[16] Salmiah. Retardasi Mental. Penerbit Universitas Sumatera Utara. Medan. 2010.

[17] Sariyem, 2011.Analisis Implementasi Program UKGS dalam Pelayanan Promotif dan Preventif di Puskesmas Wilayah Kerja Dinas Kesehatan Kota Semarang. Tesis Magister IKM UniversitasDiponegoro Semarang

[18] Shukla D, Bablani D, Chowdry A, Jafri Z, Ahmad N, Mishra S. Oral Health Status and Dental Caries Experience in Mentally Challenged Individuals. Journal Ann Public Health Res. 2014; 1(2); 1008.

[19] Sumaryanti, Wara K, Rachmah LA. 2010. Pengembangan model pembelajaran jasmani adaptif untuk optimalisasi otak Anak tunagrahita. Jurnal Kependidikan, Volume 40, Nomor 1, Mei 2010, hal. 2944. Jurusan Pendidikan dan Kesehatan Rekreasi, FIK Universitas Negeri Yogyakarta

[20] Sumini, Bibi A, Devi N. 2014. Hubungan Konsumsi Makanan Manis Dengan Kejadian Karies Gigi Pada Anak Prasekolah Di TK B RA Muslimat PSM Tegalrejo desa Semen Kecamatan Nguntoronadi Kabupaten Magetan, Jurnal Delima Harapan, Vol 3, No.2 AgustusJanuari 2014: 20-2720

[21] Wilkins EM. Clinical Practice Of Dental Hygienist $9^{\text {th }}$ edition. Lippincott Williams \& Wilkins.Massachusett-USA.2005; 348-373.

[22] Wong DL. Pedoman Klinis Keperawatan Pediatric (Wong and Whaley's Clinic paediatric Manual of Pediatric Nursing) Edisi 4. Jakarta. EGC. 2004.

Citation: Sariyem, Bedjo Santoso, Supriyana. Effectiveness of Animation Media toward Teaching Deaf Students on Dental Hygiene. ARC Journal of Dental science. 2017; 2(4): 1-4. doi:dx.doi.org/10.20431/24560030.0204001 .

Copyright: (C) 2017 Authors. This is an open-access article distributed under the terms of the Creative Commons Attribution License, which permits unrestricted use, distribution, and reproduction in any medium, provided the original author and source are credited. 